\title{
41. AGE DETERMINATIONS OF PALEOGENE DIAMICTITES FROM PRYDZ BAY (SITE 739), ANTARCTICA, USING Sr ISOTOPES OF MOLLUSKS AND BIOSTRATIGRAPHY OF MICROFOSSILS (DIATOMS AND COCCOLITHS) ${ }^{1}$
}

\author{
Hans R. Thierstein, ${ }^{2}$ J. Douglas Macdougall, ${ }^{3}$ Ellen E. Martin, ${ }^{3}$ Birger Larsen, ${ }^{4}$ John Barron, ${ }^{5}$ and Jack Baldauf ${ }^{6}$
}

\begin{abstract}
Age dating of Paleogene diamictites from ODP Site 739 in Prydz Bay with marine microfossils (diatoms and calcareous nannofossils) suggests the build-up of a major East Antarctic ice shield in latest Eocene to earliest Oligocene time, about 35-38 m.y. ago. Strontium isotopic analyses of small mollusk remains found within these diamictites, however, yield younger ages ranging from 29 to $23 \mathrm{Ma}$ (i.e., latest early Oligocene to earliest Miocene). These age discrepancies could be caused by repeated glacial reworking of microfossils, macrofossils, and sediment clasts through the late Oligocene or, alternatively, by ion exchange in the still aragonitic mollusk shells.
\end{abstract}

\section{INTRODUCTION}

At ODP Site $739\left(67^{\circ} 16.57^{\prime} \mathrm{S}, 75^{\circ} 04.91^{\prime} \mathrm{E}\right)$ a thick sequence of glacial sediments with microfossils ranging from Quaternary to late Eocene-early Oligocene age was drilled on the shelf of eastern Antarctica in the outer part of Prydz Bay in $410.3 \mathrm{~m}$ of water (Shipboard Scientific Party, 1989a). The sequence is remarkably uniform, consisting almost exclusively of pebbly mudstones (diamictites). Sediment recovery was generally poor, with the exception of the intervals $120-170$ and $200-290 \mathrm{~m}$ below seafloor (mbsf). The succession was subdivided into five lithologic units. The top unit I ( $0-24.1 \mathrm{mbsf})$ consists of consolidated diamicton with diatoms of late Pliocene to Quaternary age. Unit II (24.1-173.6 mbsf) is a hard, compacted diamictite, devoid of sedimentary structures. Diatoms found in the sediment matrix indicate an age range of early Pliocene to late Miocene. Unit III (173.6-267.2 mbsf) consists of two stratified diamictites separated by a thin interval (192.9-198.1 mbsf) of mainly gravel-free diatomaceous, sandy to silty clay. Units IV and V (267.2-486.8 mbsf) of massive diamictite are separated from the overlying unit III by an unconformity. Units III and IV contain coccoliths and diatoms considered to be of late Eocene to early Oligocene age (Shipboard Scientific Party, 1989a, p. 294-304).

The seismic data at Site 739 were interpreted as three acoustic units: (1) an upper unit (0-175 mbsf) of flat-lying, high-amplitude reflectors, considered to be variably compacted layers of Quaternary to late Miocene age, formed by possibly repeatedly advancing grounded ice sheets; (2) an intermediate unit (175$310 \mathrm{mbsf}$ ) of steeply seaward dipping, semicontinuous reflectors in sediments of probably late Eocene to lower Oligocene age, forming a prograding wedge, characterized by rapid deposition and slumping; and (3) a lowermost unit (310-487 mbsf) of gently dipping, weak, continuous reflections, possibly representing glacial conditions on a stable but subsided continental shelf (Hambrey et al., this volume).

\footnotetext{
${ }^{1}$ Barron, J., Larsen, B., et al., 1991. Proc. ODP, Sci. Results, 119: College Station, TX (Ocean Drilling Program).

2 Geological Institute, ETH-Zentrum, CH-8092 Zürich, Switzerland.

${ }^{3}$ Scripps Institution of Oceanography, University of California, La Jolla, CA 92093, U.S.A.

${ }^{4}$ Geological Survey of Denmark, Thoravey 8, 2400 Copenhagen N.V., Denmark.

${ }^{5}$ U.S. Geological Survey, 345 Middlefield Rd., Menlo Park, CA 94025, U.S.A.

6 Ocean Drilling Program, Texas A\&M University, College Station, TX 77840 , U.S.A.
}

\section{STRONTIUM, OXYGEN, AND CARBON ISOTOPES OF MOLLUSK SHELLS \\ Material and Taphonomy}

Small, fragile shells of various mollusks were found in the diamictites of Cores 119-739C-25R to 119-739C-36R (183.2$282.6 \mathrm{mbsf}$ ), recovered from the steeply seaward-dipping prograding unit, characterized by rapid deposition and slumping. Found associated with these mollusks and in other levels of this unit were rare, poorly to moderately etched nannofossils and rare to abundant, poorly to well-preserved diatoms (Shipboard Scientific Party, 1989a, Fig. 14).

More than one dozen specimens of whole shells and fragments of bivalves, scaphopods, and gastropods (all $<2 \mathrm{~cm}$ ) were sampled. Nine of the larger scaphopod and bivalve shells (Table 1) were processed for $\mathrm{Sr}$ isotopic analyses at the laboratory at Scripps Institution of Oceanography. For five of these shell samples the mineralogy was determined by X-ray diffraction at the Technical University of Denmark. With the exception of one very small sample (119-739C-29R-2, $140 \mathrm{~cm}$ ) all mollusks were analyzed for their oxygen and carbon isotopic ratios at the ETH, Zürich.

Most of the scaphopods (Dentalium sp.), a gastropod (Amauropsis sp.), and one bivalve (Aeqviyoldia sp.) were filled with and/or surrounded by yellowish diatomaceous clay, clearly different from the surrounding gray diamictite (Table 1). Fragmentation and smallness of the sampled mollusk remains did not allow more refined taxonomy. Dentalium sp., Amauropsis sp., and Aeqviyoldia sp. are known to be living in the topmost centimeter of the bottom sediments today (Dell, 1973; Powell, 1951). Most of the remaining bivalves are preserved as rounded, slightly corroded fragments interbedded in the diamictite. Their fragility and generally good preservation do not suggest long, multistage transport before burial. Small-scale, local redeposition may, however, have occurred during ice advances, which may have displaced surficial diatomaceous muds similar to those found today at Site 740 in the deep inner transverse channel, which extends parallel to the shore, or to those deposited inside iceberg grooves and sampled in the topmost part of Sites 739 and 741 .

\section{Strontium Isotope Ratios}

\section{Methods}

For strontium measurements all solid samples were cleaned repeatedly in doubly distilled water prior to dissolution. Stron- 
Table 1. Sampling levels, type of shell, and mineralogy of mollusk shells selected for isotopic work, their surrounding sediment matrix, and character of sediment filling.

\begin{tabular}{|c|c|c|c|c|c|}
\hline $\begin{array}{c}\text { Sample } \\
\text { no. }\end{array}$ & $\begin{array}{l}\text { Core, section, } \\
\text { interval }(\mathrm{cm})\end{array}$ & Shell & Mineralogy & Matrix & Sediment fill \\
\hline \multicolumn{6}{|l|}{$119-739 \mathrm{C}$ - } \\
\hline 1 & $25 \mathrm{R}-\mathrm{CC}$ & Scaphopod & Aragonite & Diamictite & Diamictite with pyrite \\
\hline 2,3 & $29 \mathrm{R}-2,69-70$ & Two bivalve fragments & Aragonite & Diamictite & - \\
\hline 4 & $29 \mathrm{R}-2,104$ & Scaphopod & $?$ & Diamictite & Diatomaceous clay \\
\hline 5 & $29 \mathrm{R}-3,123$ & Bivalve fragment & ? & Diamictite & - \\
\hline 6 & $30 \mathrm{R}-1,108$ & Gastropod (Amauropsis sp.) & Aragonite & Diamictite & Diatom ooze \\
\hline 7 & $31 \mathrm{R}-4,112-113$ & Bivalve fragment & Aragonite & Diamictite & - \\
\hline 8 & $33 R-3,125-126$ & Bivalve fragment & Aragonite? & Diamictite & - \\
\hline 9 & $33 R-5,27$ & Scaphopod & Aragonite? & Diamictite & Diatomaceous clay \\
\hline 10 & $34 \mathrm{R}-3,38$ & Scaphopod & Aragonite? & Diamictite & Diatomaceous clay \\
\hline 11 & $36 \mathrm{R}-2,143-144$ & Bivalve (Aeqviyoldia sp.) & $?$ & Diamictite & Diatomaceous clay \\
\hline \multicolumn{6}{|l|}{$119-743 \mathrm{~A}-$} \\
\hline 12 & $4 \mathrm{H}-3,8-9$ & Bivalve & Calcite & Diamicton & - \\
\hline 13 & $4 \mathrm{H}-3,88-89$ & Bivalve fragment & Calcite & Diamicton & - \\
\hline 14 & $4 \mathrm{H}-3,37$ & Bivalve fragment & $?$ & Diamicton & - \\
\hline
\end{tabular}

tium for all samples was separated by standard ion exchange procedures and analyzed by solid-source mass spectrometry. Dissolved strontium concentrations of pore waters were determined by isotope dilution. Although no replicate measurements were made for the Prydz Bay samples, multiple replicates of foraminifers from Deep Sea Drilling Project cores, analyzed during the same time period, always gave results well within the total range of variability observed during repeat analyses of NBS $987 \mathrm{Sr}$, i.e., $\pm 2.6 \times 10^{-5}$.

Ages for all samples were determined using the seawater $\mathrm{Sr}$ isotope curves established by DePaolo and Ingram (1985) and Miller et al. (1988), which incorporate the time scale of Berggren et al. (1985). All ${ }^{87} \mathrm{Sr} /{ }^{86} \mathrm{Sr}$ values were corrected for interlaboratory bias.

\section{Results}

Strontium isotope ratios of 10 samples composed of fragments of scaphopods or bivalves are listed in Table 2 (Fig. 1). One specimen was recovered from the massive diamictite of

Table 2. Strontium, oxygen, and carbon isotopic data from samples at ODP Hole 739C.

\begin{tabular}{|c|c|c|c|c|c|}
\hline Sample & $\begin{array}{l}\text { Depth } \\
\text { (mbsf) }\end{array}$ & ${ }^{87} \mathrm{Sr} /{ }^{86} \mathrm{Sr}$ & $\begin{array}{l}\text { Age } \\
(\mathrm{Ma})\end{array}$ & $\begin{array}{c}\delta^{18} \mathrm{O} \\
(\% 0 \text { PDB })\end{array}$ & $\begin{array}{c}\delta^{13} \mathrm{C} \\
\left(\%_{00} \text { PDB }\right)\end{array}$ \\
\hline \multicolumn{6}{|l|}{$119-739 \mathrm{C}-$} \\
\hline $25-\mathrm{CC}$ & 183.20 & $0.708111 \pm 26$ & 28.2 & 2.97 & 1.20 \\
\hline$a_{29-2,70}$ & 214.40 & $0.708183 \pm 26$ & 26.0 & 2.03 & -0.38 \\
\hline $29-2,140$ & 215.10 & $0.708094 \pm 26$ & 28.8 & & \\
\hline $29-3,123$ & 216.47 & $0.708089 \pm 26$ & 28.9 & 2.81 & 1.04 \\
\hline $30-1,108$ & 221.91 & $0.708308 \pm 26$ & 22.7 & & \\
\hline$a_{31-4,112}$ & 237.02 & $0.708266 \pm 26$ & 23.4 & 2.77 & -0.19 \\
\hline $33-3,125$ & 254.95 & $0.708176 \pm 26$ & 26.2 & 3.22 & 0.60 \\
\hline $33-5,27$ & 256.97 & $0.708148 \pm 26$ & 27.1 & 3.40 & 1.99 \\
\hline $34-3,38$ & 263.78 & $0.708132 \pm 26$ & 27.6 & 2.63 & -2.17 \\
\hline $36-2,143$ & 283.63 & $0.708078 \pm 26$ & 29.3 & 2.69 & -1.73 \\
\hline \multicolumn{6}{|l|}{$119-743 \mathrm{~A}-$} \\
\hline $4-3,8$ & & & & 5.00 & -0.17 \\
\hline $4-3,88$ & & & & 5.17 & 0.49 \\
\hline \multicolumn{6}{|c|}{$\begin{array}{l}\text { Note. The }{ }^{87} \mathrm{Sr} /{ }^{86} \mathrm{Sr} \text { ratio of NBS } 987 \text { is } 0.710260 \text { with a total range of } \\
\pm 0.000026 \text {, which is reported as the minimum uncertainty. The modern } \\
\text { seawater value based on } 11 \text { samples from the North Atlantic and Central } \\
\text { Pacific is } 0.709175 \text {. All ratios are fractionation corrected to an }{ }^{86} \mathrm{Sr} /{ }^{88} \mathrm{Sr} \\
\text { ratio of } 0.1194 \text {. }\end{array}$} \\
\hline
\end{tabular}

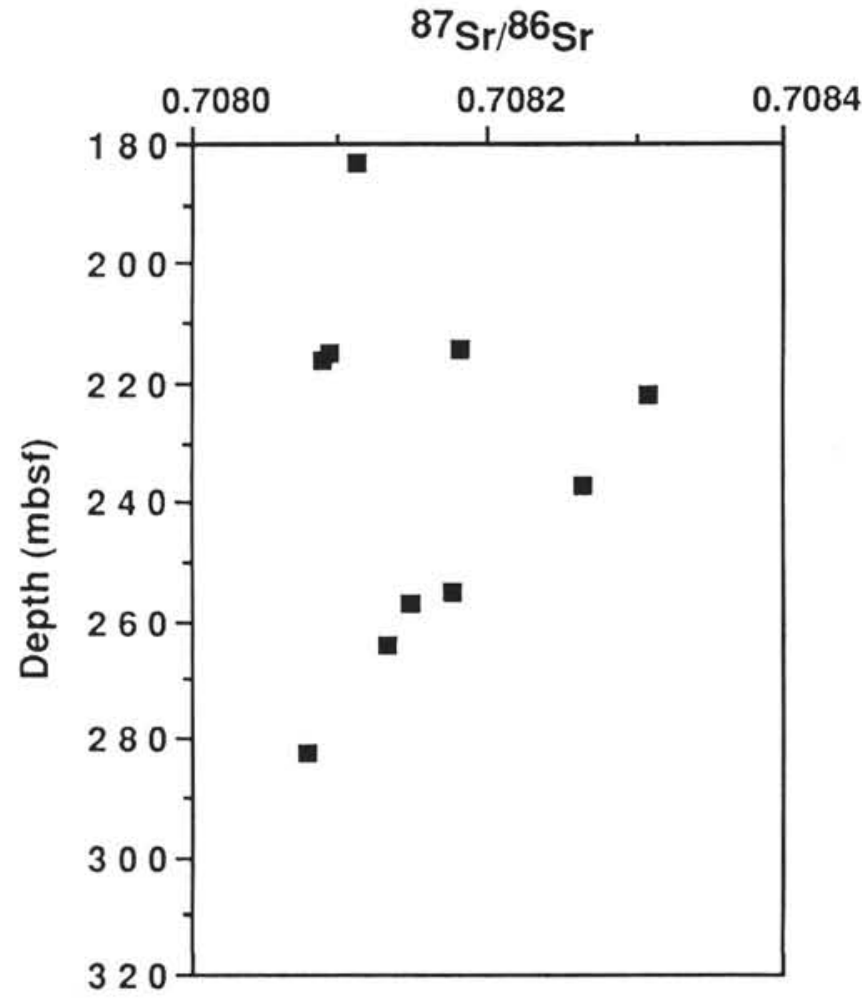

Figure $1 .{ }^{87} \mathrm{Sr} /{ }^{86} \mathrm{Sr}$ ratios of mollusk shells vs. depth (mbsf) at ODP Site 739.

Unit IV, while the remaining specimens are from the stratified diamictite of unit III. Samples 119-739C-29-2, $69 \mathrm{~cm}$, and 119$739 \mathrm{C}-31-1,112 \mathrm{~cm}$, were powdered prior to cleaning. There is a wide range of ${ }^{87} \mathrm{Sr} /{ }^{86} \mathrm{Sr}$ values from 0.708308 to 0.708078 , which correlates to late Oligocene ages of 22.7-29.2 Ma (Fig. 2). This range of ages was collected from a $100 \mathrm{~m}$ section which probably represents only about $1 \mathrm{~m}$.y. of deposition based on typical sedimentation rates for glacial environments.

Four pore water samples were analyzed for $\mathrm{Sr}$ isotopes and Sr concentration (Table 3, Fig. 3) from the interval 26-460 mbsf, including two samples within the section containing macrofossil 


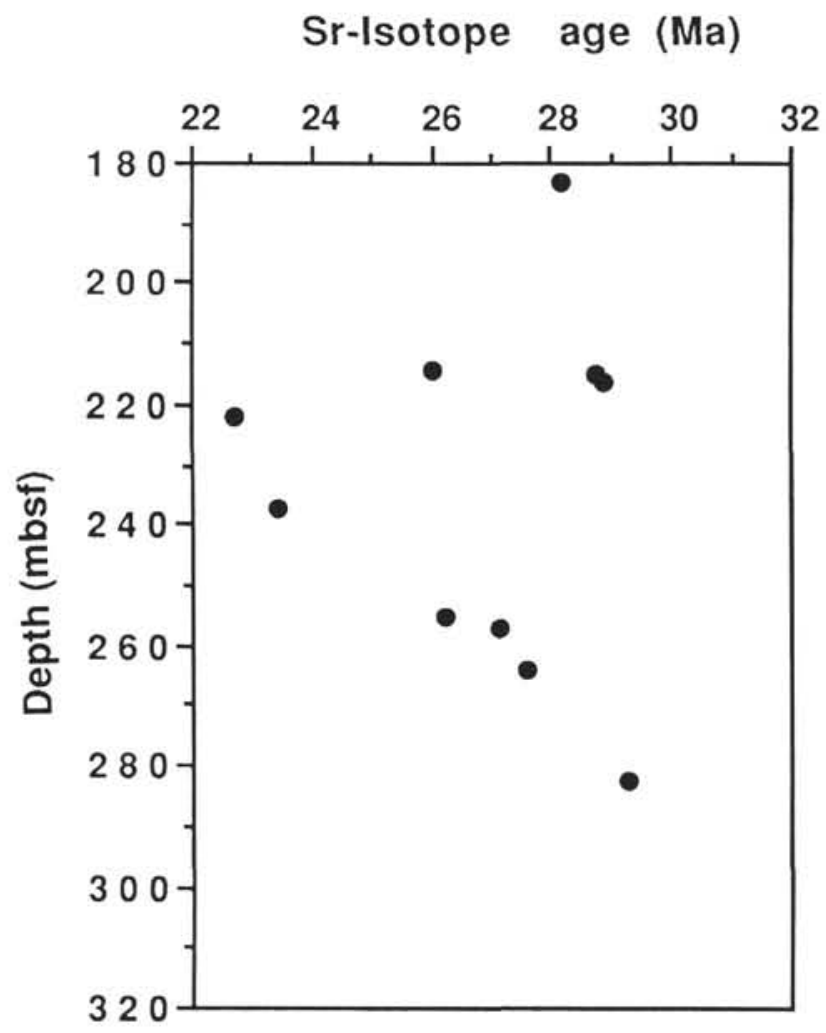

Figure 2. Age interpretation of ${ }^{87} \mathrm{Sr} /{ }^{86} \mathrm{Sr}$ ratios of mollusk shells from ODP Site 739 using the seawater curves of DePaolo and Ingram (1985) and Miller et al. (1988).

Table 3. Sr data for pore waters from ODP Site 739.

\begin{tabular}{lrrr}
\hline Sample & $\begin{array}{r}\text { Depth } \\
(\mathrm{mbsf})\end{array}$ & ${ }^{87} \mathrm{Sr} /{ }^{86} \mathrm{Sr}$ & $\begin{array}{c}\mathrm{Sr} \\
(\mu \mathrm{M})\end{array}$ \\
\hline $739-4 \mathrm{R}-2$ & 27.05 & 0.71130 & 160.2 \\
$739-28 \mathrm{R}-3$ & 206.90 & 0.71039 & 143.7 \\
$739-34 \mathrm{R}-2$ & 263.30 & 0.71034 & 132.4 \\
$739-58 \mathrm{R}-1$ & 464.60 & 0.71080 & 181.9 \\
\hline
\end{tabular}

fragments. These pore waters are 1.5-2 times enriched in dissolved $\mathrm{Sr}$ relative to seawater, and record some of the highest $\mathrm{Sr}$ isotope values reported from DSDP or ODP sites.

\section{Discussion}

The major question affecting interpretations of the strontium data is whether the fossil carbonate records the ${ }^{87} \mathrm{Sr} /{ }^{86} \mathrm{Sr}$ ratio of seawater at the time of precipitation, or has exchanged strontium with pore waters. It is difficult to distinguish between these possibilities with the current data.

X-ray-diffraction data indicate that at least three of the specimens still maintain their original aragonite composition (Table 1). There is no distinction between the ${ }^{87} \mathrm{Sr} /{ }^{86} \mathrm{Sr}$ ratios of aragonite specimens and those for which the mineral composition is questionable or untested, implying that all the fossil fragments are unaltered. These shells should record the $\mathrm{Sr}$ isotope value of contemporaneous seawater for several reasons. First, $\mathrm{Rb} / \mathrm{Sr}$ ratios in aragonite and calcite are on the order of $10^{-4}$, thus there is negligible production of ${ }^{87} \mathrm{Sr}$ by radioactive decay over the time scale of interest. Second, $\mathrm{Sr}$ isotopes are not fractionated by biological or geochemical processes, and at any rate reported

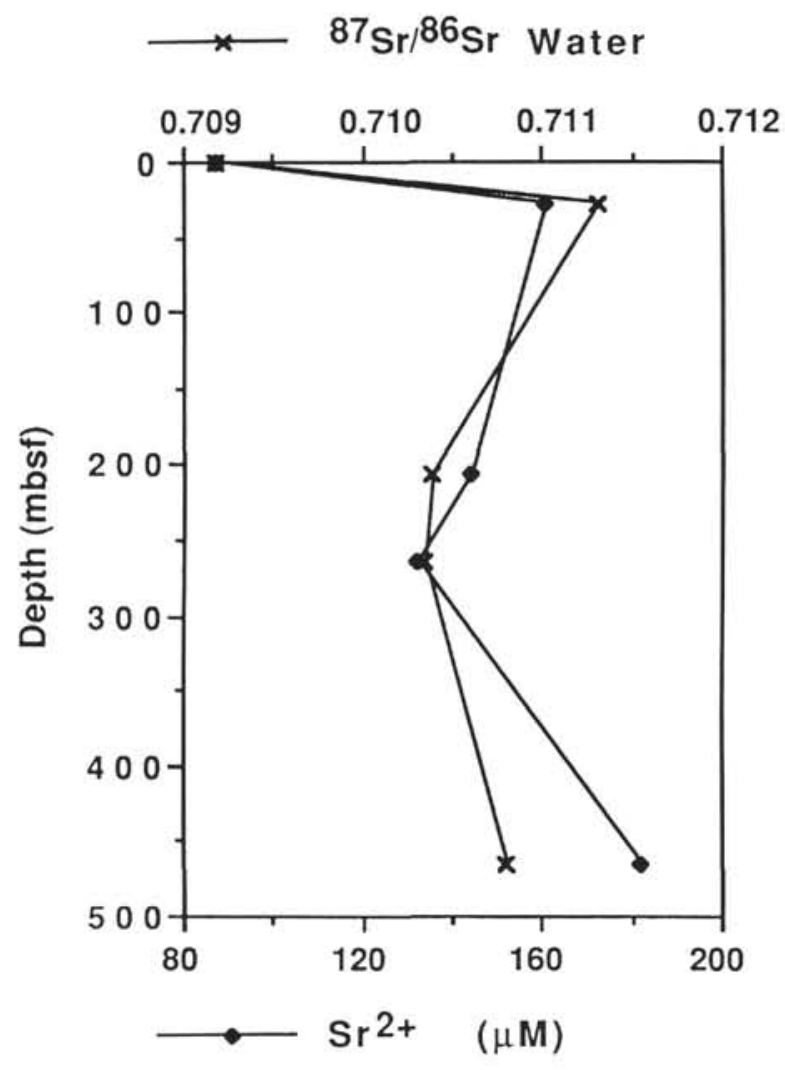

Figure $3 .{ }^{87} \mathrm{Sr} /{ }^{86} \mathrm{Sr}$ and $\mathrm{Sr}$ concentrations of pore waters vs. depth at ODP Site 739. Data points at 0 mbsf represent the modern seawater $\mathrm{Sr}$ isotope ratio and concentration.

ratios are fractionation corrected (Table 2). Finally, strontium has a long residence time (about $4 \mathrm{~m} . \mathrm{y}$.) relative to the mixing time of ocean water masses, and its isotopic composition is homogeneous throughout the world's oceans.

If the mollusk fragments do record the ${ }^{87} \mathrm{Sr} /{ }^{86} \mathrm{Sr}$ composition of source waters either there is a large difference, on the order of about $10 \mathrm{~m}$.y., between the ages of macrofossils and microfossils, or the ${ }^{87} \mathrm{Sr} /{ }^{86} \mathrm{Sr}$ composition of seawater in Prydz Bay at the time of formation of these shells was substantially higher than contemporary seawater. An association of late Oligocene mollusks and late Eocene/early Oligocene microfossils would require large-scale reworking that is consistent with the wide range of mollusk ages collected over a limited depth interval, but is inconsistent with the absence of either older macrofossils or younger microfossils within the reworked sediments.

Significant change in the $\mathrm{Sr}$ isotopic composition of Prydz Bay meltwater is also difficult to reconcile with existing data. Burke et al. (1982) and DePaolo and Ingram (1985) measured ${ }^{87} \mathrm{Sr} /{ }^{86} \mathrm{Sr}$ from a wide variety of fossil types and localities including San Francisco Bay, the Gulf of Mexico, the Mediterranean Sea, Long Island Sound, and the Persian Gulf, and demonstrated that the ratios for all fossils were equal to the modern seawater value within the stated uncertainty. In addition, a modern bivalve from the South Orkney Islands $\left({ }^{87} \mathrm{Sr} /{ }^{86} \mathrm{Sr}=\right.$ $0.709180 \pm 26$, this study) and carbonate leached from modern Maud Rise samples (Egeberg et al., in press) also yield modern seawater $\mathrm{Sr}$ isotopic values. The high concentration of strontium in seawater relative to continental runoff, $87 \mu \mathrm{M}$ vs. 0.7 $\mu \mathrm{M}$ (Goldstein and Jacobsen, 1987), and its long residence time compared to ocean mixing time, suggest it is unlikely that the ${ }^{87} \mathrm{Sr} /{ }^{86} \mathrm{Sr}$ composition of even isolated basins can be affected by 
local inputs. For example, if the fossils we have measured actually formed at $38 \mathrm{Ma}$ when seawater strontium had an isotopic ratio of 0.70784 , about $8 \%$ of the strontium they incorporated would have to be continentally derived with a ratio of 0.712 in order to result in observed values around 0.70816 (Table 2). However, because of the hundred-fold concentration difference between rivers and seawater, the resulting mixture would only contain about $10 \%$ seawater!

It is possible that even the fossils identified as being predominantly aragonite have undergone some chemical alteration. In this case the unexpectedly high ${ }^{87} \mathrm{Sr} /{ }^{86} \mathrm{Sr}$ of the macrofossils may be caused by interaction with pore waters. The measured pore water $\mathrm{Sr}$ isotopic compositions and concentrations (Table 3) indicate a substantial input of radiogenic $\mathrm{Sr}$ which is mosi likely derived from alteration of terrigenous detritus. Assuming that the pore water from 180 to 285 mbsf was initially $38 \mathrm{Ma}$ seawater, and that the excess $\mathrm{Sr}$ concentration above seawater values was generated by reaction with surrounding sediment rather than advection or diffusion of pore fluids, the ${ }^{87} \mathrm{Sr} /{ }^{86} \mathrm{Sr}$ of added strontium can be calculated from simple mixing considerations to have ${ }^{87} \mathrm{Sr} /{ }^{86} \mathrm{Sr}$ equal to 0.7155 , a reasonable value for old, continental material. The mollusk fragments would have to exchange $10 \%-17 \%$ of their strontium with the pore water in order to attain their measured ratios from an initial ratio of 0.70784 at $38 \mathrm{Ma}$.

If the gradually increasing strontium isotopic age estimates between 230 and $285 \mathrm{mbsf}$ at ODP Site 739 are used to calculate a sedimentation rate, a value of only $8 \mathrm{~m} / \mathrm{m}$.y. results, an estimate that appears exceptionally low for this type of depositional regime.

\section{Oxygen and Carbon Isotopes}

Hand-picked mollusk shell fragments were analyzed with the VG Prism mass-spectrometer at the stable isotope laboratory at the Geological Institute of the ETH. Stable isotope ratios are reported relative to PDB standard. Reproducibility of duplicate samples was better than $\pm 0.15 \%$ for $\delta^{18} \mathrm{O}$ and $\pm 0.11 \%$ for $\delta^{13} \mathrm{C}$. Except for one very small shell sample all mollusks for which strontium isotope ratios were determined were also analyzed for their oxygen and carbon isotopic values (Table 2 and Fig. 4).

The oxygen isotopic values of these late Paleogene mollusk shells range from $+1.83 \%_{0}$ to $+3.40 \%$ PDB. For comparison two calcitic bivalve shells from a late Quaternary diamicton in Samples 119-743A-4H-3, 8-9 cm (7.68 mbsf), and 119-743A$4 \mathrm{H}-3,88-89 \mathrm{~cm}$ (8.48 mbsf), were also analyzed. Their oxygen isotopic compositions were $+5.00 \%$ and $+5.13 \%$, respectively. These values are similar to the oxygen isotopic ratios measured in Quaternary deep-sea benthic foraminifera (Duplessy et al., 1988; Mackensen et al., 1989). At today's conditions, with major ice sheets on Antarctica and Greenland and with an isotopic composition of Antarctic surface waters of $-0.5 \%$ relative to SMOW (Craig and Gordon, 1965), the late Paleogene oxygen isotope values of aragonitic shells would represent paleotemperatures of $10^{\circ}$ and $5^{\circ} \mathrm{C}$, respectively (Grossman and $\mathrm{Ku}, 1986$ ); in an ice-free world, these temperature estimates would be lower by about $3.5^{\circ} \mathrm{C}$, which must be considered the lowest conceivable paleotemperature estimate for these mollusks.

Either of these water temperature estimates seems incompatible with the presence of an East Antarctic ice shield equal or larger than that of today, which would have led to Oligocene surface water temperatures near $0^{\circ} \mathrm{C}$ in Prydz Bay. This evidence and the sporadic presence of a lithologically recognizable, commonly microfossiliferous sediment matrix associated with the mollusk shells suggest, that the mollusk shells may have

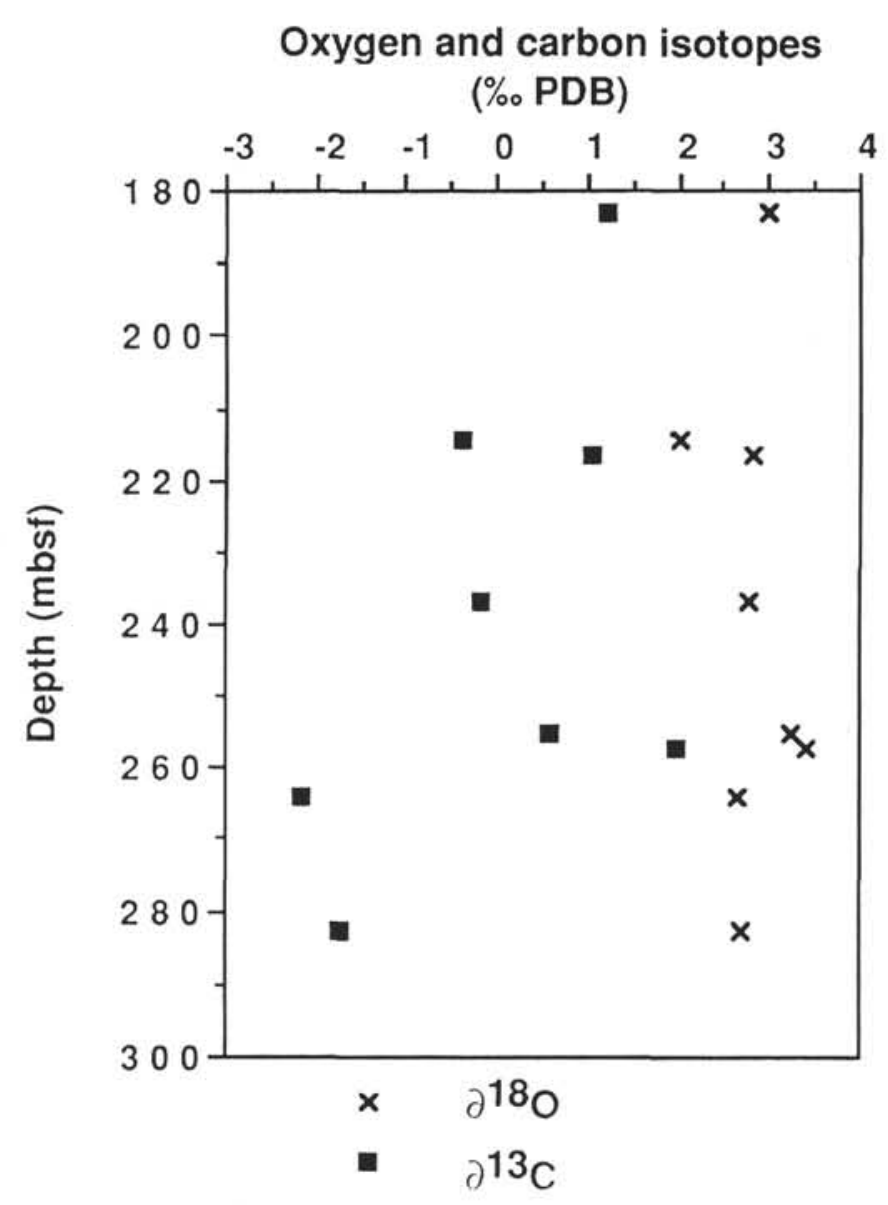

Figure 4. Oxygen and carbon isotopic composition (in \% PDB) of mollusks from ODP Site 739.

been transported and incorporated into the glacial tills during a cool period after their original deposition.

Alternatively, diagenetic exchange with generally lighter oxygen isotope ratios of marine pore waters (Savin, 1980) might have led to a shift toward less positive $\delta^{18} \mathrm{O}$ values, as observed. The oxygen isotopic composition of pore waters at Site 739 from three levels in the depth interval 263.3-397.0 mbsf has been determined to be constant at $-0.6 \%$ (Chambers, this volume). An exchange of about half of the carbonate would be required, however, to account for the observed oxygen isotopic difference between the Oligocene and Quaternary mollusks. Such extensive recrystallization is unlikely, given the pure aragonite composition and the $\mathrm{Sr}$ isotopes of the shells.

The carbon isotopic ratios of the late Paleogene mollusk shells are highly variable and range from $-2.17 \%$ to $+1.99 \%$. The large range of values correlates neither with systematic affiliation (scaphopods vs. bivalves) nor with mineralogy (verified aragonite vs. unknown). Carbon isotopic ratios of planktonic and benthic foraminifer shells from late Eocene to late Oligocene age sediments at lower latitudes (Miller and Fairbanks, 1985 ) are between $+0.5 \%$ and $+1.5 \%$. Calcitic bivalve shells from the late Quaternary at Site 743 (7.68 and $8.48 \mathrm{mbsf}$ ), which we have measured for comparison, show $\delta^{13} \mathrm{C}$ ratios of $-0.17 \%$ and $+0.49 \%$. respectively, values near the median of the Paleogene measurements. 


\section{MICROFOSSIL STRATIGRAPHY}

\section{Calcareous Nannofossils}

The nannofossils occur only sporadically in the samples from units III and IV at Site 739 and their biostratigraphic significance is discussed in Wei and Thierstein (this volume). The nannofossil age assignments in the lower part of the hole were made under the assumption that the nannofossils were mostly indigenous. This assumption seemed reasonable, because there was no mixing of nannofossils of different ages observed (in contrast to Sample 119-739C-8R-CC, at $67.3 \mathrm{mbsf}$, which contains rare Cretaceous as well as Eocene nannofossils together with common and moderately preserved Quaternary diatoms) and because the nannofossil age determinations were corroborated by contemporaneous diatom assemblages in the interval from 183 to $282 \mathrm{mbsf}$. However, with the additional age information based on the mollusk $\mathrm{Sr}$ isotope data, that interpretation may require reexamination. In the samples from the interval containing mollusk remains (183-282 mbsf) the only reasonably consistently occurring (i.e., in 42 of 56 samples examined) and dominant nannofossil is Reticulofenestra daviesii, which is known to occur in middle Eocene through late Oligocene assemblages elsewhere. Other taxa present in this interval that have relatively short and well-established stratigraphic ranges (PerchNielsen, 1985) and their respective ages in Ma (Berggren et al., 1985 ) are Chiasmolithus oamaruensis (35-40 Ma), Isthmolithus recurvus (35-38 Ma), and Reticulofenestra umbilica (35-45 Ma). They occur, however, only in five (of 56 examined) samples: 119 739C-28R-1, 30-32 cm, 119-739C-30R-1, 108-110 cm, 119-739C$30 \mathrm{R}-1,140-142 \mathrm{~cm}, 119-739 \mathrm{C}-36 \mathrm{R}-2,142-143 \mathrm{~cm}$, and $119-739 \mathrm{C}-$ $38 \mathrm{R}-1,35-37 \mathrm{~cm}$. Three additional samples (119-739C-26R-1, 68$70 \mathrm{~cm}, 119-739 \mathrm{C}-31-4,112-113 \mathrm{~cm}$, and $119-739 \mathrm{C}-35 \mathrm{R}-3,123-124$ $\mathrm{cm}$ ) contained rare Reticulofenestra samodurovii (35-45 Ma). Rare, pre-late Oligocene nannofossils thus occurred at only eight levels (i.e., at 183.9, 202.8, 222.9, 223.2, 237.0, 274.2, 282.6 , and $300.2 \mathrm{mbsf}$ ) within the mollusk-containing interval. The biostratigraphic age range for these samples is shown in Figure 5. All other 49 samples yielded nannofossils with stratigraphic ranges known to extend into the upper Oligocene.

\section{Diatoms}

Diatoms provide the primary means of stratigraphic control. Figure 8 of Baldauf and Barron (this volume) shows the stratigraphic log, core recovery, and the samples examined from this interval, as well as the assigned ages of the samples containing diatoms. Of the 60 samples examined, 35 contained diatoms. The abundance and preservation of diatoms varies, but in general, diatoms are rare and poorly preserved (see Table 11 of Baldauf and Barron, this volume). The evidence suggesting an early Oligocene age for samples examined from Cores 119. 739C-25R through 119-739C-38R is discussed in the following text.

The species observed in Cores 119-739C-25R through 119739C-38R (Baldauf and Barron, this volume, Table 11) are indicative of the Oligocene. Species characteristic of this interval include Hemiaulus characteristicus, Stephanopyxis grunowii, Melosira architecturalis, Goniothecium odontella, Pyxilla reticulata, Asteromphalus oligocenicus, Kiesielviella carina, and Pseudostictodiscus picus. An early Oligocene age is suggested by:

1. The diatom assemblages observed in Hole $739 \mathrm{C}$ indicate a sequence in stratigraphic order, from the Quaternary (Cores 119. $739 \mathrm{C}-1 \mathrm{R}$ and $119-739 \mathrm{C}-2 \mathrm{R}$ ), the ?Pliocene (Cores 119-739C-8R, 119-739C-13R, 119-739C-14R, 119-739C-18R, and 119-739C-19R), the late Miocene (Cores 119-739C-20R and 119-739C-22R) and the early Oligocene (Cores 119-739C-25R through 119-739C-38R). The assemblages observed from these chronostratigraphic intervals

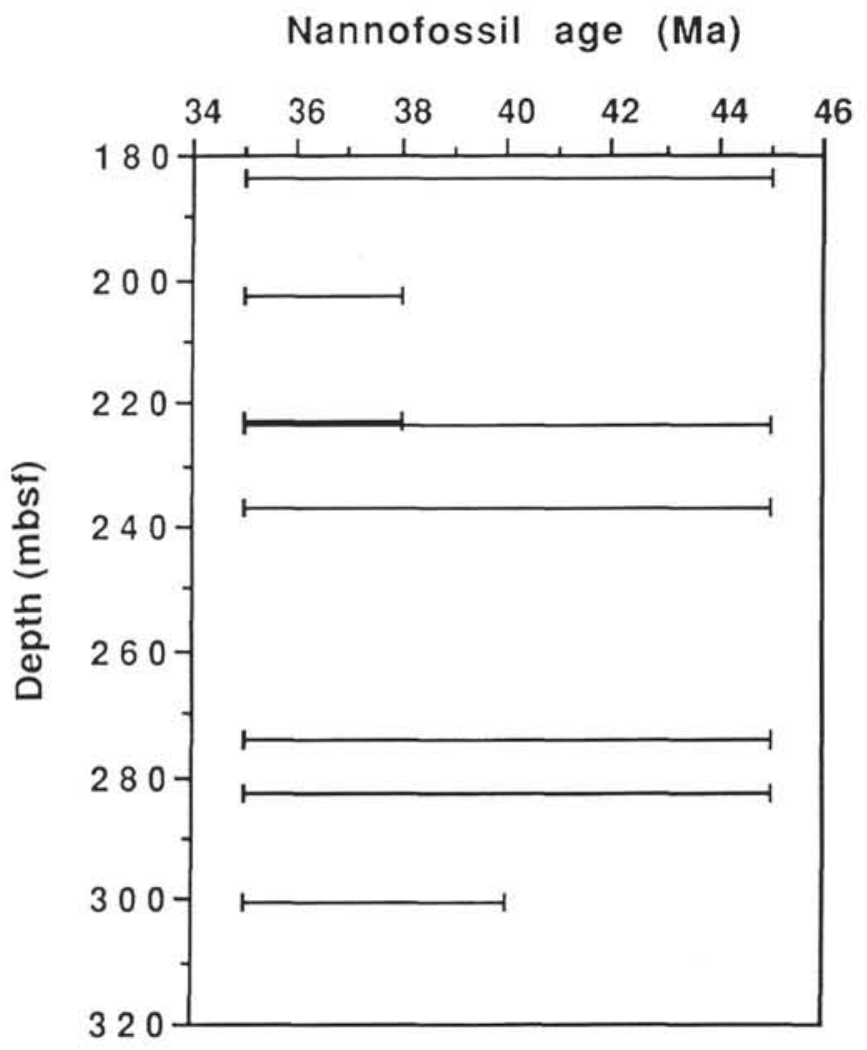

Figure 5. Age interpretation of calcareous nannofossil assemblages identified at ODP Site 739 using biostratigraphic ranges from PerchNielsen (1985) and time scale of Berggren et al. (1985).

are comparable to those observed from the Kerguelen Plateau region. An early Oligocene age is suggested by the occurrence of the species mentioned above without Rocella gelida, Rocella vigilans, or Synedra jouseana (characteristic of the late early and late Oligocene). The first occurrence of these species and other stratigraphic indicators have been calibrated with the partial magnetostratigraphy from Hole 744A (see Table 4). Assuming isochroneity of these events between Prydz Bay and the Kerguelen Plateau suggests an early Oligocene age $(\sim 35 \mathrm{Ma})$ for Core $119-739 \mathrm{C}-26 \mathrm{R}$.

2. Although ecological exclusion of the marker species from the Prydz Bay region can not be completely ruled out, the diatom assemblage observed from Cores 119-739R-25R through 119-739C-38R is similar in composition to that described by Harwood et al. (1989b) from the CIROS-1 drill core from the western Ross Sea, Antarctica. Diatoms recovered from the CIROS-1 drill site are indicative of the lower Oligocene Rhizosolenia gravida Zone of Fenner (1985). Harwood et al. (1989b) further reported that based on diatom stratigraphy, the interval representing the upper lower Oligocene (equivalent to the $R$. antarctica Zone of Fenner (1985) is missing from the CIROS-1 drill site. The base of this disconformity is constrained by the last occurrences of Pyxilla group, $H$. characteristicus, Stephanopyxis superba, S. splendidus (referred to in this manuscript as Thalassiosira hydra), Cotyledon fogedii, and Screptroneis lingulata. Directly above this disconformity is positioned the first occurrence of Synedra jouseana, and farther upsection is placed the first occurrence of Lisitziana ornata. At Site 739 a similar succession in the diatom assemblage is observed for the interval assigned to the lower Oligocene (Table 5). Of the species noted at CIROS-1, H. characteristicus (in Sections 119-739C-26R-CC, 119-739C- 
Table 4. Age calibration of diatom events based on magnetochronology and biochronology at ODP Site 744.

\begin{tabular}{lc}
\hline \multicolumn{1}{c}{ Biostratigraphic event $^{\mathrm{a}}$} & Age at Site 744 (Ma) \\
\hline FO Rocella gelida & 26.2 \\
FO Rocella vigilans & $31.2-32.2$ \\
FO Synedra jouseana & $32.5-32.8$ \\
LO Rhizosolenia gravida & $34.0-34.2$ \\
LO Hemiaulus characteristicus & $35.7-35.9$ \\
FO Rhizosolenia gravida & not determined \\
\hline
\end{tabular}

${ }^{\mathrm{a}} \mathrm{FO}=$ first occurrence; $\mathrm{LO}=$ last occurrence.

Table 5. Samples within a diatom assemblage assigned to the early Oligocene, Hole $739 \mathrm{C}$. Other samples contain diatom species of Oligocene age.

\begin{tabular}{cl}
\hline Sample & $\begin{array}{l}\text { Depth } \\
\text { (mbsf) }\end{array}$ \\
\hline 26R, CC & 192.9 \\
$32 \mathrm{R}, \mathrm{CC}$ & 250.7 \\
$30 \mathrm{R}-1,63 \mathrm{~cm}$ & 222.4 \\
a $30 \mathrm{R}-1,108 \mathrm{~cm}$ & 222.88 \\
$33 \mathrm{R}-2,80 \mathrm{~cm}$ & 253.0 \\
$33 \mathrm{R}-4,80 \mathrm{~cm}$ & 254.5 \\
$34 \mathrm{R}, \mathrm{CC}$ & 270.0 \\
$38 \mathrm{R}-1,26 \mathrm{~cm}$ & 299.16 \\
\hline
\end{tabular}

a Sediment taken from the internal mold of the snail Amauropsis sp.

30R-1, 119-739C-33R-4, 119-739C-32-CC, and Cores 119-739C35R through 119-739C-37R); S. superba (in Sections 119-739C26R-CC, 119-739C-30R-1, and 119-739C-37R-1), T. hydra (in Section 119-739C-26R-CC), and Pyxilla group (in the majority of samples) are observed and suggest a comparable age. This lower Oligocene sequence is unconformably overlain by diamictite of late Miocene age. The disconformity is constrained to Core 119-739C-24R and removes upper Oligocene through lower upper Miocene sediments.

It should be pointed out that reworking of specific diatom frustules, such as Denticulopsis hustedtii in Samples 119-739C13R-CC, 119-739C-14R-CC, and 119-739C-17R-CC, does occur. In addition, downhole contamination is also evident (occurrence of $N$. kerguelensis in Samples 119-739C-25R-1, $68 \mathrm{~cm}$, and $119-739 \mathrm{C}-29 \mathrm{R}-4,58 \mathrm{~cm}$ ).

The absence of distinctive late Oligocene diatoms in Cores 119-739C-25R through 119-739C-39 (Baldauf and Barron, this volume) implies that either these cores predate the late Oligocene or that any late Oligocene environment into which they were reworked was free of living diatoms.

\section{Evidence for Reworking}

Reworking of various microfossils in glacial sediments in and around Antarctica has been reported previously. Individual sediment pebbles containing distinct late Eocene, late Oligocene, Miocene, and Pliocene diatoms and silicoflagellates have been described from the Pliocene tills of the Sirius Formation of the Transantarctic Mountains (Webb et al., 1984). Upper Eocene to lower Oligocene diatoms have been identified in the matrix of an upper Miocene diamictite from a drill hole beneath the Ross Ice Shelf (Harwood et al., 1989a). The same diamictite also contained small clasts with distinct lower Miocene and others with distinct middle Miocene diatom assemblages. In the CIROS-1 core from McMurdo Sound a chronology was proposed that included some minor (i.e., $<2$ m.y.) age discrepancies between the magnetostratigraphy, diatom, nannofossil, foraminifer, and palynostratigraphy and a strontium isotope age of a mollusk (Harwood et al., 1989b). For the lower Oligocene a sedimentation rate of about $200 \mathrm{~m} / \mathrm{m}$.y. and for the upper Oligocene a sedimentation rate of about $40 \mathrm{~m} / \mathrm{m}$.y. were calculated for the CIROS-1 core.

Reworking of microfossils might be possible if sea ice covered Site 739 continually during deposition of this unit preventing light from reaching the water column and stimulating diatom growth. Under this scenario one would expect a fairly large source of lower Oligocene diatom-rich sediment deposited on the shelf landward from Site 739 and which would supply a constant source of early Oligocene diatoms to Site 739 throughout the late Oligocene (from 29 to $23 \mathrm{Ma}$ or age range of the strontium values). However, no such sediment rich in early Oligocene diatoms was recovered at Site 742 , even though seismic stratigraphy (Cooper et al., this volume) shows that the lower section of Site 742 is older than the interval containing early Oligocene diatoms in Hole 739C. Furthermore, this lower section at Site 742 contains very little opaline silica (Hambrey et al., this volume) and porewater chemistry does not suggest extensive solution of opaline silica (Chambers, this volume), so diagenetic alteration or solution of diatoms is not the reason for lack of diatoms in this interval.

Reworking of the lower Oligocene sediments of Cores 119739 C- 25 through $119-739$ C-39 is implied by interpretation of debris flows, slumps, and the presence of clasts containing early Oligocene diatom assemblages (Hambrey et al., this volume; Jenkins and Alibert, this volume), but diatom biostratigraphy would imply that all of this reworking occurred prior to $30 \mathrm{Ma}$ (or prior to the late Oligocene) (Baldauf and Barron, this volume; Harwood, written comm. to Barron, 1989). For example, material aged 36-34 Ma (earliest Oligocene) could be reworked in sediments aged 34-30 Ma (suggestion of Harwood, written comm.).

The generally well preserved nature of the early Oligocene diatoms and lack of diatoms of earlier age would imply that the diatoms were not subjected to mechanical processes such as one would expect in operation at the base of a glacier or grounded ice sheet (Kellogg and Kellogg, 1988).

Indeed, the presence of well-preserved diatoms implies a strong marine influence on the prograded wedge sediments of Cores 119-739C-39 through 119-739C-25 (Kellogg and Kellogg, 1988; Hambrey et al., this volume). Similarly, based on the configuration of the seismic reflectors, the upper prograding unit consists of sediments deposited on the upper paleocontinental slope between the shelf break and a level $200 \mathrm{~m}$ downslope. With the grounding point of the ice shelf at the shelf break, this implies free seawater connection beneath the floating ice shelf to the points of deposition. This fact plus the lack of any diatoms younger than early Oligocene implies that this prograded wedge was deposited in front of an ice sheet during the early Oligocene. Available knowledge of sedimentation rates at the seaward edge of a grounded ice sheet (Harwood et al., 1989b; Shipboard Scientific Party, 1989b; Hambrey et al., this volume) would imply that sedimentation rates in such an environment would be quite high ( $>100 \mathrm{~m} / \mathrm{m}$.y.), which is consistent with the unchanging nature of the diatom assemblage through $135 \mathrm{~m}$ of sediments.

\section{CONCLUSIONS}

The strontium isotopic and biostratigraphic age information give conflicting results on the timing of deposition of the macrofossils, clasts, and diamictite matrix. Reworking, transport over short distances, and incorporation of fossils and sediment clasts into the diamictites now found in Prydz Bay may be the cause of these age discrepancies. 
Alternatively, even those shells identified as aragonite by $\mathrm{X}$ ray diffraction may have undergone some $\mathrm{Sr}$ exchange with pore waters, which contain both higher concentrations of strontium than seawater and have higher ${ }^{87} \mathrm{Sr} /{ }^{86} \mathrm{Sr}$ ratios. This would require incorporation of between $10 \%$ and $17 \%$ of the total $\mathrm{Sr}$ of the shells to be from pore water with ${ }^{87} \mathrm{Sr} /{ }^{86} \mathrm{Sr}$ similar to that measured for present-day pore waters. Exchange reactions with pore waters may also be responsible for the fact that the oxygen isotopic ratios of the Oligocene mollusk shells are less positive than the Pleistocene ones. Without post-depositional alteration of the shells, the measured oxygen isotopic ratios indicate water temperatures several degrees warmer than today, which would be incompatible with the presence of a major ice cap nearby. The fact that the mollusks are still aragonitic, with no calcite present, however, remains puzzling and further trace element analyses of the shells and pore waters will be required, to verify or exclude the possibility of recrystallization (Rosenthal et al., 1989; Rosenthal and Katz, 1989).

These results illustrate the difficulties in establishing a reliable chronology in shallow-water, glacial sediment sequences and thus the limitations of current techniques to date the initiation of major ice buildup on East Antarctica in sediments recovered from the shallow continental shelf.

\section{ACKNOWLEDGMENTS}

We thank Judy McKenzie and Franz Gönner for helping us with the measurement of the oxygen and carbon isotope ratios, David Harwood for discussions and for providing unpublished information, and Daniel Müller and an anonymous reviewer for critical remarks on drafts of the manuscript.

\section{REFERENCES}

Berggren, W. A., Kent, D. V., Flynn, J. J., and Van Couvering, J. A., 1985. Cenozoic geochronology. Geol. Soc. Am. Bull., 96:1407-1418.

Burke, W. H, Denison, R. E., Hetherington, E. A., Koepnick, R. B., Nelson, H. F., and Otto, J. B., 1982. Variation of seawater ${ }^{87} \mathrm{Sr} /{ }^{86} \mathrm{Sr}$ throughout Phanerozoic time. Geology, 10:516-519.

Craig, H., and Gordon, L. I., 1965. Deuterium and oxygen 18 variations in the ocean and the marine atmosphere. In Tongiorgi, E. (Ed.), Stable Isotopes in Oceanographic Studies and Paleotemperatures, Spoleto, 1965: Pisa (Consiglio Nazionale delle Ricerche, Laboratorio di Geologia Nucleare), 9-130.

Dell, R. K., 1973. Antarctic benthos. Adv. Mar. Biol., 10:1-216.

DePaolo, D. J., and Ingram, B. L., 1985. High-resolution stratigraphy with strontium isotopes. Science, 227:938-940.

Duplessy J. C., Shackleton, N. J., Fairbanks, R. G., Labeyrie, L., Oppo, D., and Kallel, N., 1988. Deepwater source variations during the last climatic cycle and their impact on the global deepwater circulation. Paleoceanography, 3:343-360.

Egeberg, P. K., Smalley, P. C., and Aagaard, P., 1990. Strontium isotope geochemistry of Leg 113 interstitial waters and carbonates. In Barker, P. F., Kennett, J. P., et al., Proc. ODP, Sci. Results, 113: College Station, TX (Ocean Drilling Program), 147-157.

Fenner, J., 1985. Late Cretaceous to Oligocene planktonic diatoms. In Bolli, H. M., Saunders, J. B., and Perch-Nielsen, K. (Eds.), Plankton Stratigraphy: Cambridge (Cambridge Univ. Press), 713-762.
Goldstein, S. J., and Jacobsen, S. B., 1987. The Nd and Sr isotopic systematics of river-water dissolved material: implications for the sources of Nd and $\mathrm{Sr}$ in seawater. Chem Geol., 66:245-272.

Grossman, E. L., and Ku, T. L., 1986. Oxygen and carbon isotope fractionation in biogenic aragonite: temperature effects. Chem. Geol., 59:59-74.

Harwood, D. M., Scherer, R. P., and Webb, P. -N., 1989a. Multiple Miocene marine productivity events in West Antarctica as recorded in upper Miocene sediments beneath the Ross Ice Shelf (Site J-9). Mar. Micropaleontol., 15:91-115.

Harwood, D. M., Barrett, P. J., Edwards, A. R., Rieck, H. J., and Webb, P.-N., 1989b. Biostratigraphy and chronology. In Barrett, P. J., (Ed.) Antarctic Cenozoic History from the CIROS-1 Drillhole, McMurdo Sound. DSIR Bull. N. Z., 245:67-97.

Kellogg, T. B., and Kellogg, D. E., 1988. Antarctic cryogenic sediments: biotic and inorganic facies of ice shelf and marine-based ice sheet environments. Palaeogeogr., Palaeoclimatol., Palaeoecol., 67:51-74.

Mackensen, A., Grobe, H., Hubberten, H. W., Spieß, V., and Fütterer, D. K., 1989. Stable isotope stratigraphy from the Antarctic continental margin during the last one million years. Mar. Geol., 87:315321.

Miller, K. G., and Fairbanks, R. G., 1985. Oligocene to Miocene carbon isotope cycles and abyssal circulation changes. In Sundquist, E. T., and Broecker, W. S. (Eds.), The Carbon Cycle and Atmospheric $\mathrm{CO}_{2}$ : Natural Variations Archean to Present. Am. Geophys. Union Geophys. Monogr., 32:469-486.

Miller, K. G., Feigenson, M. D., Kent, D. V., and Olsson, R. K., 1988. Upper Eocene to Oligocene isotope $\left({ }^{87} \mathrm{Sr} /{ }^{86} \mathrm{Sr}, \delta^{18} \mathrm{O}, \delta^{13} \mathrm{C}\right)$ standard section, Deep Sea Drilling Project Site 522. Paleoceanography, 3: 223-233.

Perch-Nielsen, K., 1985. Cenozoic calcareous nannofossils. In Bolli, H. M., Saunders, J. B., and Perch-Nielsen, K. (Eds.), Plankton Stratigraphy: Cambridge (Cambridge Univ. Press), 427-554.

Powell, A.W.B., 1951. Antarctic and subantarctic mollusca: Pelecypoda and Gastropoda. Discovery Rep., 26:47-196.

Rosenthal, Y., and Katz, A., 1989. The applicability of trace elements in freshwater shells for paleogeochemical studies. Chem. Geol., 78:6576.

Rosenthal, Y., Katz, A., and Tchernov, E., 1989. The reconstruction of Quaternary freshwater lakes from the chemical and isotopic composition of gastropod shells: the Dead Sea Rift, Israel. Palaeogeogr., Palaeoclimatol., Palaeoecol., 74:241-253.

Savin, S. M., 1980. Oxygen and hydrogen isotope effects in low-temperature mineral-water interactions. In Fritz, P., and Fontes, J. Ch. (Eds.), Handbook of Environmental Isotope Geochemistry (Vol. 1): Amsterdam (Elsevier), 283-327.

Shipboard Scientific Party, 1989a. Site 739. In Barron, J., Larsen, B., et al., Proc. ODP, Init. Repts., 119: College Station, TX (Ocean Drilling Program), 289-344.

1989b. Site 743. In Barron, J., Larsen, B., et al., Proc. ODP, Init. Repts., 119: College Station, TX (Ocean Drilling Program), 459-476.

Webb, P. N., Harwood, D. M., McKelvey, B. C., Mercer, J. N., and Stott, L. D., 1984. Cenozoic marine sedimentation and ice-volume variation on the East Antarctic craton. Geology, 12:287-291.

Date of initial receipt: 2 January 1990

Date of acceptance: 16 July 1990

Ms 119B-178 